\title{
The Effects of Entrepreneurial Orientation and Commitment to Objectives on Performance
}

\author{
Mark Simon \\ Chanele Stachel \\ Jeffrey G. Covin
}

7 he relationship between entrepreneurial orientation (EO) and performance is often moderated by different factors. Specifically, scholars have called for research examining whether commitment to long-term objectives improves EO's effectiveness, believing that commitment may belp firms overcome obstacles associated with EO. In response, we collected survey data from executives in 126 small, high-technology firms, and found that EO and commitment to objectives enbanced sales growth. In addition, the study determined that commitment to objectives was associated with greater increased sales growth of companies high in EO, as compared to those low in $E O$.

Keywords: entrepreneurial orientation; commitment to objectives; small business; sales growth; performance

Entrepreneurial orientation (EO) refers to firm behavior and strategy that emphasizes aggressiveness, risk-taking, and innovation (Miller and Friesen, 1982). In recent decades, researchers have conducted more than 100 studies of EO, many of which focused on its effects on performance (Rauch, Wiklund, Lumpkin, Frese, 2009; Wang, 2008). This effort is consistent with Rauch and colleagues' (2009) belief that it is "essential" to explore the relationship between EO and performance, given EO's many potential benefits. The benefits may include generating new ideas and creative processes (Covin and Slevin, 1989) and improving a firm's competitive position (Chang, Lin, Chang, and Chen, 2007). Furthermore, EO may even be crucial to a firm's survival (Kropp and Zolin, 2005) by helping firms deal with many challenges (McCrea and Betts, 2008; Mintzberg and Waters, 1982) such as those associated with crisis, dynamic environments, uncertainty, and stagnant growth.

The potential benefits above might lead one to conclude EO dramatically improves performance. Close examination of the literature (e.g., Rauch et al., 2009; Wang, 2008), however, has not conclusively established this relationship. Instead, as suggested by multiple scholars (e.g., Covin, Green and Slevin, 2006; Rauch et al., 2009; Wang, 2008; Wiklund and Shepherd, 2005) when, if, and the extent to which EO improves organizational performance may depend upon additional factors. It may be especially important to examine characteristics of a firm's strategic management process, where the strategic management process refers to the methods by which organizations (1) establish their long-term objectives and (2) choose actions to reach those objectives (Chandler, 1962). A fundamental principle of the strategic management literature is that these characteristics often influence the relationship between the type of strategies (e.g., entrepreneurial strategies) and the end results of those strategies.This principle led Miller and Friesen in 1982, Lumpkin and Dess in 1996, Barringer and Bluedorn in 1999, Wiklund and Shepherd in 2003, Covin and colleagues in 2006 and De Clercq as recently as 2010 , to argue the EO field needs more studies examining how characteristics of the firm's strategic management process might influence the relationship between EO and performance.

One characteristic, namely a firm's commitment to longterm objectives, might be especially important to the effectiveness of EO (Covin et al., 2006; De Clercq, Dimov, and Thongpapanl, 2010). Many (e.g., Barringer and Bluedorn, 1999; Covin et al., 2006; Ferreira, 2001) have implicitly or explicitly implied that commitment to long-term objectives may help firms pursuing EO cope with one of their greatest challenges, namely imposing the order needed to keep a firm results oriented while still providing the freedom needed to innovate and take risks. Consistent with this belief, Ferreira (2001) theorized that the success of EO may depend on having a strong identification with the organization's mission and commitment to its formal goals. Yet, despite calls to do so (Covin et al., 2006; De Clercq et al., 2010; Rauch et al., 2009), no empirical research has explored whether the effect of entrepreneurial orientation on performance depends on level of commitment to long-term objectives. The current article fills this gap.

We focus on small, high-technology manufacturing firms in a hostile environment because they more often display entrepreneurial strategies (Rauch et al., 2009). As such, it becomes most imperative to identify moderators that make those strategies effective. Furthermore, small and high-technology businesses play a vital role in our economy. The following section reviews the relevant literature on EO and presents the hypotheses. We then describe the research 
methods and report the empirical tests of the hypothesized relationships. Finally, the article discusses the study's findings and implications.

\section{Entrepreneurial Orientation}

EO is a major topic within both the strategic management and entrepreneurship literatures (Covin, et al., 2006). Arguably, EO research falls into three main categories. The first category is represented by studies that explore how firms can become more entrepreneurial (e.g., Burgelman, 1983; Brazeal, Schenkel, and Azriel, 2008). This stream of literature focused on how managers might overcome the natural barriers to entrepreneurship, such as risk aversion and bureaucratic cultures (Hisrich and Peters, 1986). These studies indicated that many factors, including CEO personality (Simsek, Heavey, and Veiga, 2010), organizational structure (Covin and Slevin, 1990); scanning behavior (Schafer, 1990), incentives (Arbaugh, Cox, and Camp, 2004) and championing behavior (Hisrich and Peters, 1986) may influence the extent to which firms exhibit entrepreneurial behavior.

Much of this work assumed, but did not directly test, that EO enhanced performance. Instead, a second set of EO studies emerged to empirically examine this issue. The stream grew at a phenomenal pace, with journals publishing five times as many studies on EO and performance from 2000 to 2009 as they did from 1990 to 1999 (Rauch et al., 2009). These studies generated inconsistent findings, however, with some determining that EO was strongly and positively associated with firm performance, (e.g., Lee and Tsang, 2001; Wiklund and Shepherd, 2003), others detecting only a weak positive relationship (e.g., Lumpkin and Dess, 2001; Zahra, 1991) and still others uncovering no significant linkage (Covin, Slevin, and Schutz, 1994; George, Wood, and Khan, 2001). Going one step further, Hart (1992) even theorized that EO could lower performance under certain conditions.

These conflicting results spurred a third category of EO research (which admittedly often overlapped with the second). Often, inconsistent conclusions across studies stem from unidentified constructs, known as moderators, which influence the relationship between two variables. Thus, several scholars (Rauch et al., 2009; Covin et al., 2006) stress the need to identify moderators that might influence the EO-performance relationship. In response, research has uncovered several factors, including environmental dynamism (Wiklund and Shepherd, 2005) environmental hostility (Miller and Friesen, 1982), technological intensity (Zahra, 1996) and early industry lifecycle stage (Lumpkin and Dess, 2001), that increase the effectiveness of EO. To date, however, the majority of the moderators identified are related to a firm's external surroundings (De Clercq et al., 2010; Rauch et al., 2009).

This focus on the external, while undoubtedly beneficial, did little to increase understanding of how executives can effectively and strategically manage entrepreneurial behaviors, a task that is often formidable. To produce positive performance, EO often requires overcoming significant resistance, interpreting ambiguous settings, and establishing new procedures and practices (Hisrich and Peters, 1986). Thus, scholars have suggested research focus on identifying characteristics of the strategic management process that might help managers overcome the challenges in implementing EO (Covin et al., 2006; Lumpkin and Dess, 1996; Wiklund and Shepherd, 2003). This emphasis has generated several significant findings. For example, strategic management processes that allow for emergent strategies (Covin et al., 2006), involve longer planning horizons (Miller and Friesen, 1982), promote autocratic decision making (Covin et al., 2006), foster flexible planning (Miller and Friesen, 1982), create trust (De Clercq et al., 2010), and incorporate feedback from failed earlier initiatives (Covin et al., 2006), all increase the success of EO.

Interestingly, however, no study has explicitly examined whether one of the most important characteristics of the strategic management process, namely commitment to longterm objectives, moderates the EO-performance relationships. Although untested, the assertions of several scholars suggest empirically exploring this question might generate valuable insights. Covin and his colleagues (2006) explicitly argued that commitment and objectives might play a crucial role when engaging in entrepreneurial actions. Similarly, De Clercq and colleagues (2010) suggested that by internalizing organizational goals, committed managers can enhance their firm's entrepreneurial potential. Finally, Rauch and colleagues' (2009) assertion that decision makers use EO to achieve and sustain their long-term objectives suggests the need to explore the role which commitment to those objectives may play.

In keeping with past research exploring interactions (e.g., Simon, Elango, Houghton, and Savelli, 2002), we will initially formulate hypotheses relating to the direct effects of variables on performance, and then formulate a hypothesis about the effects of an interaction term. Our first hypothesis examines the direct effect of EO on performance. While the relationship between the two is not universally unwavering, a direct relationship might be detected in specific settings (Rauch et al., 2009), such as among small, high-technology firms, which is the current study's setting. High-technology firms often exist in environments consisting of rapid change and shortened product and business model lifecycles, suggesting that profits from existing operations are short-lived and uncertain. As such, EO may be especially beneficial. To keep revenues from drying up in these settings, firms need to seek out new opportunities constantly and frequently innovate (Callaway, Celuch, and Murphy, 2009). This belief is consistent with findings from empirical studies (Rauch et al., 2009) that determined EO enhances the performance of 
high-technology firms more than it enhances the performance of low-technology firms.

Firms that are smaller might also be better able to implement EO effectively. Wiklund (1999) explains that the EO-performance relationship may be particularly strong among small firms because smallness fosters the flexibility needed to make EO initiatives successful. However, it also limits their ability to compete in other ways. In a later piece, Wiklund and Shepherd (2005) explained EO provides small businesses the ability to find and/or discover new opportunities that can differentiate them from other firms and create a competitive advantage. Similarly, Slater and Narver (1995) argued EO can help small companies create breakthrough products or new markets not only ahead of competitors but before customers can even recognize their need, and in so doing generate positive financial results. These arguments are consistent with Rauch and colleagues' (2009) meta-analysis results, namely that the EO-performance relationship was strongest among small firms. Collectively, the paragraphs above suggest the following hypothesis:

\section{H1: Entrepreneurial orientation is positively associat- ed with small firm performance.}

In addition to EO, commitment to objectives may affect performance. Commitment to objectives refers to the determination to try to achieve a goal, without abandoning or lowering it (Hollenbeck and Klein, 1987). In many situations commitment can enhance firm performance by increasing effort and generating goal-directed behaviors (Klein and Kim, 1998). As such, scholars (e.g., Klein and Kim, 1998) have argued that commitment to objectives is a key to effective goal setting. Such commitment can serve to point organizational members in the same direction, allowing a firm to achieve better results (de Waal, 2010).

Theory and empirical research both suggest, that while not universal, quite often there is a positive relationship between commitment to objectives and performance (Locke, Latham, and Erez, 1988). We believe this relationship applies to our sample of firms, given its characteristics. Commitment is most likely to be effective when managers can influence outcomes, a situation that is more likely in small organizations, such as those we studied. Consistent with this belief, Kuratko, Covin, and Garrett (2009) found small corporate ventures were more likely to thrive when the venture's goals were clear. Commitment is also especially vital to the performance of high-technology manufacturing firms. Udo and Ehie (1996), for example, found commitment, and clarity of objectives made implementing advanced manufacturing technologies more successful. Finally, it should be noted that a long-term orientation, as might be reflected by commitment to long-term objectives, enhances the perform- ance of companies facing hostile environments (Covin and Slevin, 1989), a situation no doubt faced by our sample of Midwest manufacturing firms from states such as Michigan. Thus, it follows:

\section{H2: Commitment to long-term objectives is positively associated with small company performance.}

While the two previous hypotheses suggest that, in the context of this study, both EO and commitment to long-term objectives enhance performance, the question remains, will commitment to objectives enhance the performance of firms with greater EO, more than it will enhance the performance of firms lower in EO? To answer this question, we examine two challenges a firm faces when trying to implement EO. The first is that entrepreneurial organizations simultaneously must facilitate freedom and impose control (Burgelman, 1983). EO, with its innovative and risky actions, implicitly necessitates that companies allow managers the autonomy and flexibility to act (Covin et al., 2006; Wang, 2008). Such freedom, however, implies the strategies will have very unpredictable outcomes and a significant possibility of failure. Thus, it may be difficult to hold managers accountable and may be counterproductive to encourage people to experiment, and yet "demand" results. By the same token, allowing managers to do "whatever" regardless of outcome is unlikely to enhance a firm's performance.

Instilling a commitment to long-term objectives in these entrepreneurial settings may help resolve this potential paradox. Instead of managers just "trying things," commitment to long-term objectives will keep managers focused on making attempts until they succeed. As such, commitment to longterm objectives might play an important role in allowing freedom to act, while at the same time making sure individuals are responsible for producing results. In contrast, less entrepreneurial firms, by definition, are proceeding along welldefined paths, with more predictable outcomes. They achieve results by following well-known strategies rather than "finding" a way to succeed. While commitment to long-term objectives might still benefit them, it may be less necessary.

The second major challenge entrepreneurial firms face is internal resistance to their initiatives (Hisrich and Peters, 1986). Instead of trying to execute EO wholeheartedly, many managers tend to view the strategies negatively because of their downside risk, and are therefore reluctant to become involved (Hisrich and Peters, 1986). Such an attitude, if not dooming the initiative to failure, at the very least makes it more difficult to achieve success. Thus, it is not surprising that Henley (2007) stressed entrepreneurial firms need to counteract resistance by providing a powerful push. Stimulating a strong commitment to long-term objectives can provide this push. The managers' positive focus on ways to 
achieve objectives is likely to displace their tendency to stress downside risk. By more fully supporting the initiatives, they are more likely to succeed. In contrast, less entrepreneurial initiatives, by definition, usually are not as risky and are, therefore, less likely to encounter similar resistance.Thus, commitment to long-term objectives may be less important.

Research in related areas supports the idea that a strong push, whether from commitment to objectives or other means, may be crucial to EO's success. For example, autocratic decision making (Covin et al., 2006) and a centralized structure (Miller and Friesen, 1982) both increased the relationship between EO and performance. Similarly, while not directly measuring objectives, De Clercq and colleagues (2010) found higher levels of organizational commitment strengthened the link between EO and performance. Similarly, Murphy and Callaway (2004) argued that emotional commitment to entrepreneurial ventures might lead to higher persistence and better performance. Collectively, the above suggests the following hypothesis:

H3: The greater the commitment to objectives, the more positive the relationship between $\mathrm{EO}$ and performance.

\section{Methods}

We contacted 591 top-level executives of small (500 employees or fewer), high-technology manufacturing firms in five Midwest states (Michigan, Ohio, Indiana, Illinois, and Wisconsin), asking them to complete a Web-based survey. We focused on this type of firm because small and/or high-tech companies in hostile environments more often need entrepreneurial strategies to compete (Mintzberg, 1973), suggesting it is crucial for them to utilize EO effectively. Of those contacted, 126 filled out the survey completely, generating a response rate of 21 percent. Among other variables, the survey measured the level of the firm's EO, commitment to longterm objectives, and sales growth. We have reproduced the measures in Figure 1.

\section{Measures}

We measured EO using a 6-item, bipolar 7-point scale adapted from Covin and Slevin (1990).To calculate EO, we took the average of the individual item scores. Higher scores on the scale indicated a greater EO. Inter-item reliability was .82 . Commitment to objectives was measured using a 4-item, 7point scale. We used the average of the four items to calculate the variable, generating an inter-item reliability of .89 . The higher the score, the greater the commitment was to the objectives. We used firm sale growth rate as our study's measure of firm performance.The sales growth rate was measured based on the average growth in sales revenue over that threeyear period (2004-2007). Because the growth varies by industry, we subtracted the industry's average growth rate over this period from each average growth rate. We used sales growth rate to capture firm performance because EO is, essentially, a growth orientation (Lumpkin and Dess, 1996). Thus, EO effectiveness is appropriately measured using criteria that reflect a firm's success at translating entrepreneurial opportunities into growth trajectories (Covin et al., 2006).

\section{Analysis}

We used hierarchical multiple regression to examine the study's hypotheses, using sales growth as the dependent variable. The regression was conducted in two steps. We entered EO and commitment to objectives in step 1. After this, we interpreted the results of the direct effects of EO and commitment on sales growth. In step 2, we entered the interaction term to determine if it had additional explanatory power beyond the first two variables entered. Consistent with the recommendations of Aiken, West, and Reno (1991), to capture the interaction of EO and commitment to objectives, we first centered and scaled each variable, and then multiplied them together to compute their product.

Table 1 displays the intercorrelations among the study's variables. All correlations were below .50 , suggesting multicollinearity is not a problem. Table 2 provides the result of the hierarchical regression analysis. Model 1 testing the direct effects was significant $(\mathrm{R} 2=.05, \mathrm{p}<.05)$. As predicted, EO was positively and significantly associated with sales growth $(\beta=.17, \mathrm{p}<.05)$, supporting Hypothesis 1 . Hypothesis 2, that commitment to objectives increased sales growth, was not, however, supported ( $\beta=.10$, n.s.). Model 2 , which tested the interaction term, was significant $(\mathrm{R} 2=.09$, $\mathrm{p}<.01)$. In the model, the interaction of commitment to objective and EO was also significant $(\beta=-.26, \mathrm{p}<.01)$, supporting Hypothesis 3.

\section{Discussion}

Concurrent with companies' increasing desire to be more entrepreneurial, the body of research on EO and performance has been growing at a rapid rate (Ferreira, 2001). With this growth, however, has come the recognition that EO does

\begin{tabular}{|l|r|r|c|c|}
\hline \multicolumn{5}{|c|}{ Table 1. Means, Standard Deviations, and } \\
Correlations \\
\hline Variables & Mean & Std. Dev. & 1 & 2 \\
\hline 1. Sales growth & .13 & .28 & & \\
\hline $\begin{array}{l}\text { 2. Entrepreneurial } \\
\text { Orientation }\end{array}$ & 4.04 & 1.20 & $.17^{*}$ & \\
\hline $\begin{array}{l}\text { 3. Commitment to } \\
\text { Objectives }\end{array}$ & 5.50 & .97 & $.13 \mathrm{t}$ & $.22^{* *}$ \\
\hline \\
$\begin{array}{l}\mathrm{t} \mathrm{p}=<0.1,{ }^{*} \mathrm{p}=<0.05,{ }^{* *} \mathrm{p}=<0.01 . \\
\mathrm{n}=127, \text { One-tail tests results are reported. }\end{array}$
\end{tabular}


Entrepreneurial Orientation: To measure entrepreneurial orientation, we used the scale below.

In general, the top managers of my business unit favor ...

A strong emphasis on the marketing of "tried- $\begin{array}{llllllllll}1 & 2 & 3 & 4 & 5 & 6 & 7 & \text { A strong emphasis on R\&D, technological }\end{array}$ and-true" products or services

leadership, and innovations

How many new lines of products or services has your business unit marketed during the past three years?
No new lines of product or services
$\begin{array}{lllllll}1 & 2 & 3 & 4 & 5 & 6 & 7\end{array}$
Very many new lines of products or services
Changes in product or service lines
$\begin{array}{lllllll}1 & 2 & 3 & 4 & 5 & 6 & 7\end{array}$
Changes in product or service lines have
have been mostly of a minor nature usually been quite dramatic

In general, the top managers of my business unit have...
A strong proclivity for low-risk projects (with
$\begin{array}{lllllll}1 & 2 & 3 & 4 & 5 & 6 & 7\end{array}$
A strong proclivity for high-risk projects
normal and certain rates of return)
(with chances of very high returns)

In general, the top managers of my business unit believe that ...

Owing to the nature of the environment, it is $\begin{array}{llllllll}1 & 2 & 3 & 4 & 5 & 6 & 7\end{array}$

best to explore it gradually via cautious,

incremental behavior

Owing to the nature of the environment, bold, wide-ranging acts are necessary to achieve the firm's objectives

When confronted with decision-making situations involving uncertainty, my business unit ...

Typically adopts a cautious, "wait-and-see" $\quad \begin{array}{lllllll}1 & 2 & 3 & 4 & 5 & 6 & 7\end{array}$ posture in order to minimize the probability of making costly decisions
Typically adopts a bold, aggressive posture in order to maximize the probability of exploiting potential opportunities

Commitment to Long-term Objectives:To measure commitment to long-term objectives, we used the scale below. Individuals recorded their response to each statement using a 1 to 7 scale ranging from strongly disagree to strongly agree.

1. My business unit's top managers are absolutely committed to the achievement of our long-term objectives.

2. My business unit's top managers would be very reluctant to change our long-term objectives unless overwhelming evidence compelled us to do so.

3. My business unit's top managers have strongly and personally embraced our long-term objectives as compellingly appropriate business goals.

4.There is a strong belief among our top managers that our long-term objectives are the correct ones for us.

\section{Figure 1. Measures}

not automatically lead to higher performance, and that the relationship between the two may be more complex than originally envisioned. Scholars have asserted that understanding this complexity and, thereby, determining how to maximize the effectiveness of EO is crucial, because pursuing EO often demands substantial resources and is, by definition, risky (Rauch et al., 2009).

The current study responds to this concern and answers calls (e.g., Covin et al., 2006; Zahra, 1991) to examine whether characteristics of a firm's strategic management processes, such as commitment to objectives, moderates the relationship between EO and performance. We uncovered several relationships. EO had a direct positive effect on sales growth, at least among small, high-technology firms. The interaction of EO and commitment to objectives also significantly influenced performance. As shown in Figure 2, commitment to objectives benefits the performance of companies higher in EO more than it benefits the performance of companies lower in EO. In fact, commitment to objectives appears to have no effect on performance overall, or on the performance of the low EO companies.

Although not directly tested, we believe the study's find- 


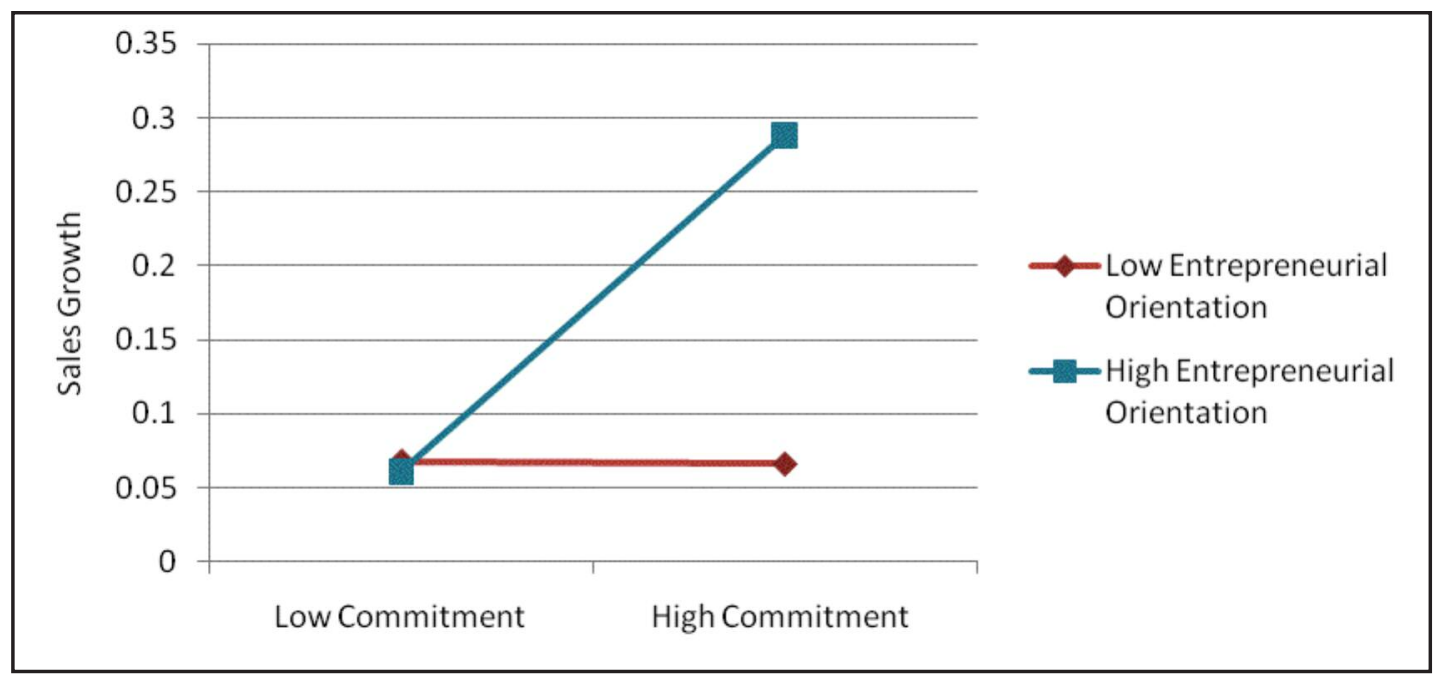

Figure 2. Interaction of Entrepreneurial Orientation and Commitment to Objectives

ings might provide insights into a fundamental dilemma posed by EO. To succeed, EO needs both discipline and flexibility (Burgelman, 1983; Simon et al., 2002). Yet on the surface, maintaining order while providing the freedom to innovate might seem paradoxical. We believe that imposing discipline through commitment to long-term objectives might help untangle this paradox. Such commitment might allow firms to try many different things, while constantly keeping focus on the firm's overall long-term goals. As such, the firm can constantly move toward improving its performance. Scholars can advance EO research more directly by examining this issue.

\begin{tabular}{|c|c|c|}
\hline \multicolumn{2}{|c|}{ Table 2. Results of Hierarchical Regression Analysis } \\
\hline Predictor Variable & Model 1 & Model 2 \\
\hline Step 1: Independent var & & \\
\hline Entrepreneurial Orientation & .17 & $.16^{*}$ \\
\hline Commitment to Objectives & .10 & .24 \\
\hline Step 2: Interaction & & \\
\hline Ent. Orient. *Comm. to Obj. & & $.26^{* * *}$ \\
\hline$\Delta \mathrm{R}^{2}$, change from Prev. Model & & .05 \\
\hline$\Delta \mathrm{F}$, change from Prev. Model & & $6.30^{* * *}$ \\
\hline $\mathrm{R}^{2}$ & .05 & .09 \\
\hline Adjusted ${ }^{2}$ & .03 & .07 \\
\hline $\mathrm{F}$ & $3.00^{*}$ & $4.19^{* * *}$ \\
\hline
\end{tabular}

${ }^{*} \mathrm{p}=<0.05,{ }^{* *} \mathrm{p}=<0.01$.

$\mathrm{n}=127$, One-tail tests results are reported.
Future research also needs to address some of the current study's limitations. First our data was crosssectional, making it difficult to infer causality. Rather than high levels of EO and commitment to long-term objectives leading to sales growth, it is at least possible that sales growth leads to EO and commitment to long-term objectives. While we do draw our conclusions from extant theory, further research would provide additional insight by studying EO and performance over time.

A second limitation stems from the study's dependent variable, firm sales growth rate, which may, or may not, be related to another very important measure of firm performance, namely, profitability. It should be noted, however, that sales growth may be especially appropriate for assessing a firm's effectiveness when pursuing entrepreneurial opportunities, which is inherently a growth-oriented activity (Covin et al., 2006; Davidsson and Henrekson, 2002). Furthermore, Rauch and colleagues' (2009) meta-analysis indicated that the relationship between EO and performance is robust with regards to different performance measures, implying that findings related to sales growth may also apply to profitability. Nevertheless, the EO research would benefit by replicating this study's finding using measures of profitability.

Limitations notwithstanding, the study results suggest several actions managers might consider to enhance performance. First, firms may want to increase commitment to longterm objectives when pursuing EO. Scholars suggest several methods to accomplish this (for a comprehensive review see Locke et al., 1988). Perhaps, no factor is as important as that of leadership. Locke and colleagues (1988) explained that legitimate authority is a key determinant of goal commitment, and that the ability to engender such commitment is one of the most important characteristics of successful leaders.

To engender commitment, leaders must closely tie both internal and external rewards to objectives (Locke et al., 
1988). Given that these rewards can be costly, however, it may prove most important for only firms high in EO to offer them, where commitment is most important.Another important lever to foster commitment is clearly communicating objectives (de Waal., 2010; Ebert, 2010). Such communication provides organization members the same frame of reference and aligns their actions. Clear communication is especially crucial to spur commitment, given findings that leaders often believe they have conveyed an objective, but employees feel it has not been shared (Ebert, 2010).

Our study results also indicate that small technology firms may benefit by increasing EO. There are several actions that may accomplish this task (Ferreira, 2001; Zahra, 1991). A firm's level of entrepreneurship depends on individuals below top management (Stevenson and Jarillo, 1990) and on senior executives (Guth and Ginsberg, 1990; Morrow, 2002). Operational-level participants can engage in environmental scanning to notice entrepreneurial opportunities (Schafer, 1990) and more importantly, take actions to exploit them (Ferreira, 2001).

There are, however, many steps senior executives should take to create a climate that facilitates the efforts of lower- level employees. Perhaps, first and foremost, they must build a culture that values entrepreneurial behavior (Guth and Ginsberg, 1990) by using several levers that are at their disposal. They can incentivize risk-taking (Arbaugh et al., 2004) and lessen any negative consequences when an isolated short-term initiative fails to achieve a desired interim outcome (Stevenson and Jarillo, 1990). Instead, they must provide employees the freedom to try different actions and adopt a long-term perspective (Barringer and Bluedorn, 1999). Senior management should also provide a significant quantity of high-quality communications about industry trends, ideas, and perhaps most of all, the importance of EO (Ferreira, 2001).

In summary, the current study answers the call of researchers to explore how commitment to long-term objectives might influence the EO-performance relationship. We explored this issue among small, high-technology firms because they have a particularly high need to implement EO effectively. Given the riskiness of entrepreneurial strategies, it is our hope this study serves as a building block for future work on how to improve EO's outcomes.

\section{References}

Aiken, L.S., West, S.G., and Reno, R. 1991.Multiple Regression:Testing and Interpreting Interactions. Sage Publications, Thousand Oaks, Ca.

Arbaugh, J. B., Cox, L. W. and Camp, S. M. 2004. Employee Equity, Incentive Compensation, and Growth in Entrepreneurial Firms. New England Journal of Entrepreneurship 7(1), 15-25

Barringer, B.R., Bluedorn,A. C. 1999. The Relationship Between Corporate Entrepreneurship and Strategic Management. Strategic Management Journal 20(5), 421

Brazeal, D., Schenkel, M., and Azriel, J. 2008. Awakening the Entrepreneurial Spirit: Exploring the Relationship Between Organizational Factors and Perceptions of Entrepreneurial Self-Efficacy and Desirability in a Corporate Setting. New England Journal of Entrepreneurship 11(1), 9-25.

Burgelman, R.A. 1983.A Model of the Interaction of Strategic Behavior, Corporate Context, and the Concept of Strategy. Academy of Management Review 17(1), 61-70.

Callaway, S., Celuch, K., and Murphy, G. 2009. Strategic Flexibility and SMEs:The Role of Information Technology for Managing Internal and External Relations. New England Journal of Entrepreneurship 12(1), 9-17.

Chang, S., Lin, R., Chang, F and Chen, R. 2007.Achieving Manufacturing Flexibility through Entrepreneurial Orientation. Industrial Management and Data Systems 107(7), 997-1017.

Chandler, A. D., Jr. 1962. Strategy and Structure: Chapters in the History of the American Industrial Enterprise. Cambridge, MA: MIT Press

Covin, J. G., Green, K., and Slevin, D. P. 2006. Strategic Process Effects on the Entrepreneurial Orientation-Sales Growth Rate Relationship. Entrepreneurship Theory and Practice 30(1), 57-81.

Covin, J. G., and Slevin, D. 1989. Strategic Management of Small Firms in Hostile and Benign Environments. Strategic Management Journal 10(1), 75

Covin, J. G., and Slevin, D. P. 1990. New Venture Strategic Posture, Structure, and Performance:An Industry Life Cycle Analysis. Journal of Business Venturing 5, 123-135.

Covin, J. G., Slevin, D. P., and Schultz, R. L. 1994. Implementing Strategic Missions: Effective Strategic, Structural and Tactical Choices. The Journal of Management Studies 31(4), 481. 
Davidsson, P., and Henrekson, M. 2002. Determinants of the Prevalence of Start-Ups and High-Growth Firms. Small Business Economics 19(2), 81.

De Clercq, D., Dimov, D., and Thongpapanl, N. 2010. The Moderating Impact of Internal Social Exchange Processes on the Entrepreneurial Orientation-Performance Relationship. Journal of Business Venturing 25(1), 87.

de Waal,A. 2010. Performance-driven Behavior as the Key to Improved Organizational Performance. Measuring Business Excellence 14(1), 79-95.

Ebert, E. J. 2010.The Surprisingly Low Motivational Power of Future Rewards: Comparing Conventional Money-based Measures of Discounting with Motivation-based Measures. Organizational Behavior and Human Decision Processes 111(2), 71 .

Ferreira, J. 2001. Corporate Entrepreneurship:A Strategic and Structural Perspective. New England Journal of Entrepreneurship 4(2), 59.

George, G., Wood, D., and Khan, R. 2001. Networking Strategy of Boards: Implications for Small and Medium-Sized Enterprises. Entrepreneurship and Regional Development:An International Journal 13(3), 269-285.

Guth,W., and Ginsberg,A. 1990. Guest Editors' Introduction: Corporate Entrepreneurship. Strategic Management Journal $11(5), 5$.

Hart, Stuart L. 1992. An Integrative Framework for Strategy-Making Processes. The Academy of Management Review 17(2), 327.

Henley, L. G. 2007. Extending Innovation Boundaries: Corporate Venture Capital Gives Large Firms a Strategic Option. The Journal of Business Strategy 28(5), 36-43.

Hisrich, R. D., and Peters, M. P. 1986. Establishing a New Venture Business Unit within a Firm.Journal of Business Venturing $1,307-322$.

Hollenbeck, John R., and Klein, Howard J. 1987. Goal Commitment and the Goal-Setting Process: Problems, Prospects, and Proposals for Future Research. Journal of Applied Psychology 72(2), 212.

Klein, H. J., and Kim, J.S. 1998. A Field Study of the Influence of Situational Constraints, Leader-Member Exchange, and Goal Commitment On Performance. Academy of Management Journal 41(1), 88-95.

Kropp, F. and Zolin, R. 2005. Technological Entrepreneurship and Small Business Innovation Research Programs. Academy of Marketing Science Review 2005(7), 1.

Kuratko, D., Covin, J., and Garrett, R. 2009. Corporate Venturing: Insights from Actual Performance. Business Horizon. 52(5), 459.

Lee, D.Y., and Tsang, E. W. K. 2001. The Effects of Entrepreneurial Personality, Background and Network Activities on Venture Growth.Journal of Management Studies 38(4), 583-602.

Locke, E.A., Latham, G. P., and Erez, M. 1988. The Determinants of Goal Commitment. The Academy of Management Review 13(1), 23.

Lumpkin, G.T., and Dess, G. G. 1996. Clarifying the Entrepreneurial Orientation Construct and Linking It to Performance. The Academy of Management Review 21(1), 135.

Lumpkin, G.T., and Dess, G. G. 2001. Linking Two Dimensions of Entrepreneurial Orientation to Firm Performance:The Moderating Role of Environment and Industry Life Cycle, Journal of Business Venturing 16(5), 429-451.

McCrea, E., and Betts, S. 2008. Failing to Learn from Failure:An Exploratory Study of Corporate Entrepreneurship Outcomes. Academy of Strategic Management Journal 7, 111-132.

Miller, D., and Friesen, P. H. 1982. Innovation in Conservative and Entrepreneurial Firms:Two Models of Strategic Momentum: Summary. Strategic Management Journal 3(1), 1.

Mintzberg, H. 1973. Strategy-Making in Three Modes. California Management Review 16,(2), 44.

Mintzberg, H., and Waters, J.A. 1982. Tracking Strategy in an Entrepreneurial Firm. Academy of Management Journal 25(3), 465.

Morrow, J. L. Jr. 2002. Someone Old or Someone New? The Effects of CEO Change on Corporate Entrepreneurship. New England Journal of Entrepreneurship 5(2), 21-34.

Murphy, G. B., and Callaway, S. K. 2004. Doing Well and Happy About It? Explaining Variance in Entrepreneurs' Stated Satisfaction with Performance. New England Journal of Entrepreneurship 7(2), 15-26. 
Rauch,A., Wiklund, J., Lumpkin, G., and Frese, M. 2009. Entrepreneurial Orientation and Business Performance:An Assessment of Past Research and Suggestions for the Future. Entrepreneurship Theory and Practice 33(3), 761-787.

Schafer, S. 1990. Level of Entrepreneurship and Scanning Source Usage in Very Small Business. Entrepreneurship:Theory and Practice 15, 19-32.

Simon, M., Elango, B., Houghton, S. M, and Savelli, S. 2002. The Successful Product Pioneer: Maintaining Commitment While Adapting to Change. Journal of Small Business Management 40(3), 187-203.

Simsek, Z., Heavey, C., and Veiga, J. 2010. The Impact of CEO Core Self-Evaluation on the Firm's Entrepreneurial Orientation. Strategic Management Journal 31(1), 110.

Slater, S. F., and Narver, J. C. 1995. Market Orientation and the Learning Organization.Journal of Marketing 59(3), 63.

Stevenson, H.H., and Jarillo, J. 1990.A Paradigm of Entrepreneurship: Entrepreneurial Management. Strategic Management Journal 11(5), 17.

Udo, G., and Ehie, 1996. Advanced Manufacturing Technologies Determinants of Implementation Success. International Journal of Operations and Production Management 16(12), 6-26.

Wang, C. 2008. Entrepreneurial Orientation, Learning Orientation, and Firm Performance. Entrepreneurship Theory and Practice 32(4), 635-657.

Wiklund, J. 1999. The Sustainability of the Entrepreneurial Orientation-Performance Relationship. Entrepreneurship Theory and Practice 24(1), 37-48.

Wiklund, J., and Shepherd, D. 2005. Entrepreneurial Orientation and Small Business Performance:A Configurational Approach. Journal of Business Venturing 20(1), 71-91.

Wiklund, J., and Shepherd, D. 2003. Knowledge-Based Resources, Entrepreneurial Orientation, and the Performance of Small and Medium-Sized Businesses. Strategic Management Journal 24(13), 1307

Zahra, S.A. 1991. Predictors and Financial Outcomes of Corporate Entrepreneurship:An Exploratory Study. Journal of Business Venturing 6(4), 259-285.

Zahra, S.A. 1996. Technology Strategy and New Venture Performance:A Study Of Corporate-Sponsored And Independent Biotechnology Ventures.Journal of Business Venturing 11(4), 289.

\section{About the Authors}

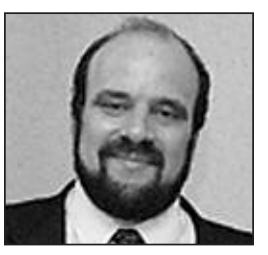

MARK Simon (simon@oakland.edu) is an associate professor of management at Oakland University. He has published articles related to entrepreneurial orientation and small business.

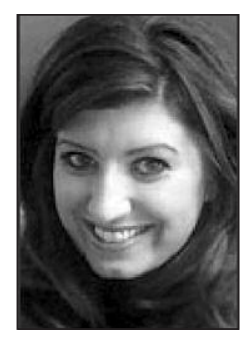

Chanele Stachel (chanelestachel@gmail.com ) is a recent graduate from Oakland University earning a degree in finance. Her research interests include small businesses and entrepreneurship.

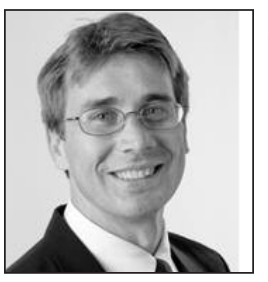

JEFFREY G. Covin (covin@indiana.edu ) is the Samuel and Pauline Glaubinger Professor of Entrepreneurship at the Kelley School of Business, Indiana University, Bloomington. His research interests include corporate entrepreneurship, strategic management, and technology management. 